\title{
Investigation of recent catastrophic landslides in the flysch belt of Outer Western Carpathians (Czech Republic): progress towards better hazard assessment
}

\author{
J. Klimeš ${ }^{1}$, I. Baroň² ${ }^{2}$ T. Pánek ${ }^{3}$, T. Kosačík ${ }^{3}$, J. Burda ${ }^{4}$, F. Kresta ${ }^{5}$, and J. Hradecký ${ }^{3}$ \\ ${ }^{1}$ Institute of Rock Structure and Mechanics, Praha, Czech Republic \\ ${ }^{2}$ Czech Geological Survey, Brno, Czech Republic \\ ${ }^{3}$ University of Ostrava, Ostrava, Czech Republic \\ ${ }^{4}$ Charles University, Prague, Czech Republic \\ ${ }^{5}$ SG-Geotechnika Inc., Ostrava, Czech Republic
}

Received: 4 April 2008 - Revised: 17 November 2008 - Accepted: 14 January 2009 - Published: 13 February 2009

\begin{abstract}
Rapid snow melting and intense precipitation triggered and reactivated tens of mostly shallow landslides in the eastern part of the Czech Republic at the turn of March and April 2006. This area is build up by highly fractured flysch rock units with variable content of sandstones and claystones. The landslide complex at Hluboče (Brumov-Bylnice town) is composed of shallow translational (up to $10 \mathrm{~m}$ thick) as well as deep-seated (up to $20 \mathrm{~m}$ thick) rotational landslides, which generated a catastrophic earthflow at their toe. This earthflow destroyed three buildings, the access road and caused total loss of about 350000 EUR. Detailed field investigation, review of the archive sources and interviewing of local inhabitants allowed brief description of slope movement history prior the catastrophic event as well as detailed reconstruction of slope failure mechanisms during the main movement activity (3-4 April 2006). This information, along with the detailed description of the passive as well as active causative factors (structural and morphologic settings) can contribute towards better identification of potentially dangerous slope failures in the study region.
\end{abstract}

\section{Introduction}

The entire region of the Outer Western Carpathians has intensively experienced both, past and recent mass-wasting activity. Such processes in the area of the flysch Carpathians are usually caused by heavy rainfalls. The region is character-

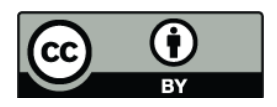

Correspondence to: J. Klimeš

(jklimes@centrum.cz) ized by average precipitation of $900-1000 \mathrm{~mm}$ per year and the best-documented historical landslide acceleration took place after the July 1997 floods, when an average of $257 \mathrm{~mm}$ of precipitation fell down during 5 days (Kirchner, 2001) in the eastern part of the Czech Republic. During this landslide event more than 1500 landslides of different types (e.g. soil slips, flows and translational landslides) originated causing extensive damage to buildings and infrastructure. Notable is the fact that about $40 \%$ of the active landslides occurred in relation to older, mainly deep-seated slope failures (Krejčí et al., 2002).

At the beginning of April 2006, more than 80 of mostly shallow landslides evolved during large landslide event in the mountainous eastern part of the Czech Republic (Bíl and Müller, 2008). During this period the landslide and earthflow complex Hluboče was also triggered. It developed in the Bílé Karpaty Highlands in the vicinity of the BrumovBylnice town in the site called Hluboče, $3.5 \mathrm{~km} \mathrm{~W}$ from the state border with Slovakia (Fig. 1). It is the longest active landslide complex (Table 1) that has been observed in the territory of the Czech Republic since the July 1997 event. Fortunately the Hluboče landslide complex did not develop in densely inhabited area. However, it completely destroyed three buildings, damaged unpaved road, electric power line as well as part of the forest. The local authorities estimated total loss to about 350000 Euro.

The paper presents results of field mapping, eyewitness reports, aerial photography interpretation and electrical resistivity tomography (ERT) investigations revealing causes and mechanisms of the origin and development of the landslide complex. 


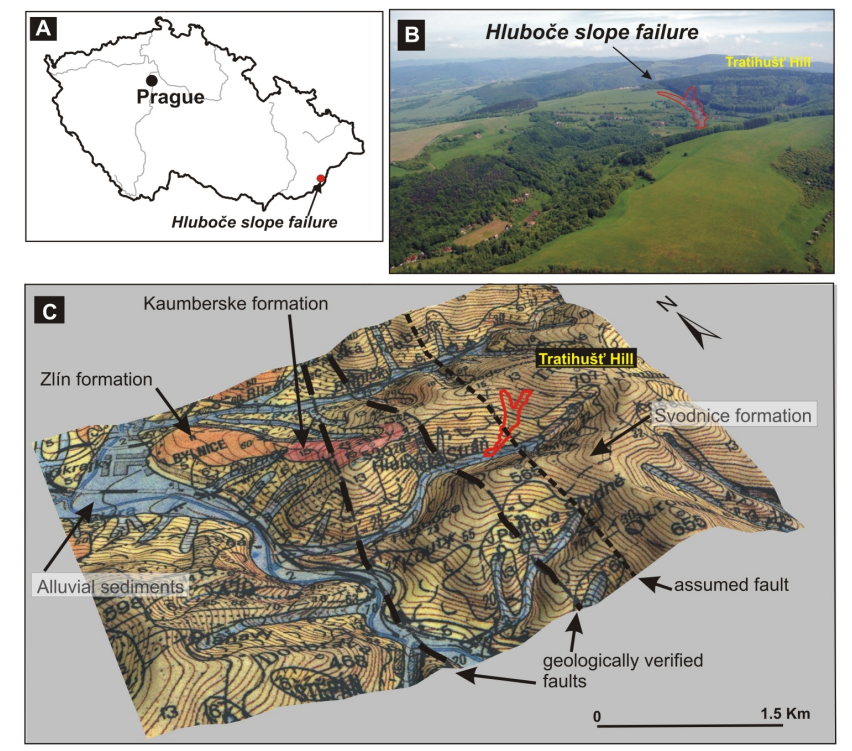

Fig. 1. (A) - location of the study site, (B) - oblique aerial view of the Hluboče landslide complex (to the NE, foto I. Baroň, 2006), (C) - topographic and geological overview.

\section{General geological and morphological setting}

The Hluboče landslide complex is situated on the southfacing slope of the Tratihušt' Mt. (707 ma.s.1.) which has gradient between $10-20^{\circ}$ with the maximum inclination of $\sim 30^{\circ}$ in the central part of the slope and with local relief up to $300 \mathrm{~m}$. Upper part of the slope has broad concave horizontal curvature with shallow dell-like depression in its lower part reaching the valley floor.

In general, the Flysch Belt of the Outer Western Carpathians comprises mainly of folded alternating claystone, shale, and sandstone beds of Mesozoic and Tertiary age. The Czech part of the Flysch Belt is an allochthonous nappe system that was thrust over the West European Plate and part of its foredeep from the southeast during Paleogene and Early Neogene orogeny (Pícha et al., 2004). Host bedrock of the studied landslide complex consists of the Svodnice Formation of Magura Unit, with very abundant claystone and shale rocks which produced rather thick weathering mantle. Structural and tectonic conditions of the study site remain largely unknown due to critical lack of bedrock outcrops both within the landslide complex and its surrounding. The only structural information can be approximated from the geological map at scale 1:50 000 which suggests that the bedding may be almost conform to the ground surface reaching the inclination between $20-50^{\circ}$ to the S and SE (Krejčí, 1992).

Despite of the lack of outcropping bedrock with measurable tectonic features, thrust, normal and left-lateral faults should be expected here due to nappe structure and close position of the collision zone of the Klippen Belt (oblique collision between the Central Carpathians and the European
Table 1. Morphometric characteristics of the Hluboče complex landslide.

\begin{tabular}{ll}
\hline Characteristics & Value \\
\hline Maximum length & $770 \mathrm{~m}$ \\
Maximum width & $110 \mathrm{~m}$ \\
Length to width ration & 7 \\
Surface & $60000 \mathrm{~m}^{2}$ \\
Maximum depth & $10-20 \mathrm{~m}$ \\
Volume* & $40000-140000 \mathrm{~m}^{3}$ \\
Movement velocity** & $0.6-0.8 \mathrm{~m} / \mathrm{h}$ \\
Maximum altitude at crown & $605 \mathrm{~m}$ \\
Minimum altitude at foot & $419 \mathrm{~m}$ \\
Difference of altitude & $186 \mathrm{~m}$ \\
Average slope gradient & $14^{\circ}$ \\
\hline
\end{tabular}

* calculated volume using formulas in Malamud et al. (2004)

** measured on site during the landslide activity

Platform, Pícha et al., 2004). Based on analysis of the SRTM (Shuttle Radar Topography Mission) digital terrain models (NASA) and geological map (Krejčí, 1992), the expected left-lateral fault systems have mostly NE-SW and N-S strike (Fig. 1). The two faults (Krejčí, 1992) of N-S direction are cutting the mountain ridge in the vicinity of the landslide complex (Fig. 1c).

\section{Methods}

The first observations and video recording of the Hluboče landslide complex provided local inhabitants and forest workers, who tried to protect buildings from moving trees. Interviewing of these people allowed detailed reconstruction of failure mechanism and its antecedent conditions.

Geomorphic field mapping, mineralogical analyses of the sediments and ultra-light airplane observations (Baroň et al., 2007) were used to complete necessary information about the landslide complex. Radiocarbon AMS dating of one sample taken from the older landslide body underlying contemporary Hluboe landslide complex was performed in the Radiocarbon Laboratory of the Institute of Physics, Silesian University of Technology (Gliwice, Poland, Fig. 2).

The kinematics and spatial characteristic of the landslide complex were studied on a set of aerial ortho-photographs from 2003 and summer 2006 in ArcGIS 9.2 software (ESRI). The analysis enabled us to roughly summarize values and vectors of the horizontal displacements of the objects recognized on the both ortho-photographs. Analysing stereo-pairs of historical aerial photographs as well as dendrochronologic analysis allowed detailed reconstruction of activity of the studied landslide complex. Aerial photographs from the years 1950, 1977, 1990, 2003 and 2006 were used for the stereoscopic analysis. Dendrochronologic research on 

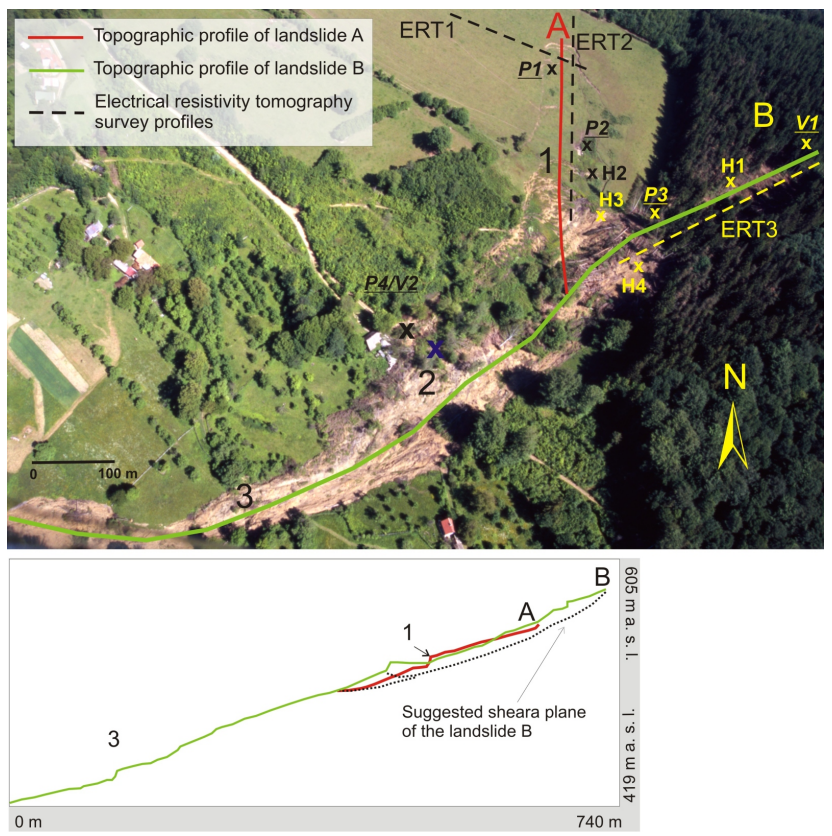

Fig. 2. Oblique aerial view of the studied landslide (foto J. Klimeš, 2006) showing topographic as well as ERT profiles, $1-5 \mathrm{~m}$ high scarp, 2 - artesian spring occurred during the landslide movement, 3 - location of the third house destroyed by the earthflow, H1-H4 locations of sediment samples for mineral analyses, P1-P4 are sites of dynamic penetration tests, V1-V2 are boreholes locations and $\mathrm{H} 4-$ is location of the sample taken for the radiocarbon AMS dating.

eccentricity of annual tree-rings as a result of tree tilting was done to proof mass-movement activity between 1937 and 2006. Dendrochronologic drilling cores as well as digital photographs of tree stumps were taken from all parts of the landslide "B" (e.g. toe, flanks, block, crown). The cores were measured by standard dendrochronologic method (optical microscope, "dendrochronological timetable") while the digital images of tree rings of 7 stumps were analysed by OSM 3 software (SCIEM). These images were taken 2 years after the landslide event. The identified eccentricities were weighted based on the Ei (eccentricity) value where Ei between 0.1 and 0.5 received weight 1 and tree-rings with $\mathrm{Ei}$ greater than 0.5 weight 2 .

Internal structure of the landslide complex was investigated by electrical resistivity tomography (ERT) survey, core drillings and dynamic penetration testing. Three ERT profiles lead along the longer axis of the both "A" and "B" landslides and perpendicularly to the "A" landslide (Fig. 2). The Schlumberger electrode array was chosen for the resistivity measurements and the resulting apparent resistivity pseudosection was transformed into a model representing continuous distribution of calculated electrical resistivity in the subsurface by RES2Dinv software.

Two $6 \mathrm{~m}$ deep boreholes (V1 and V2), surveyed by the NordMayer Machine were situated above the "B" landslide and at a place of one of the destroyed buildings. Af-

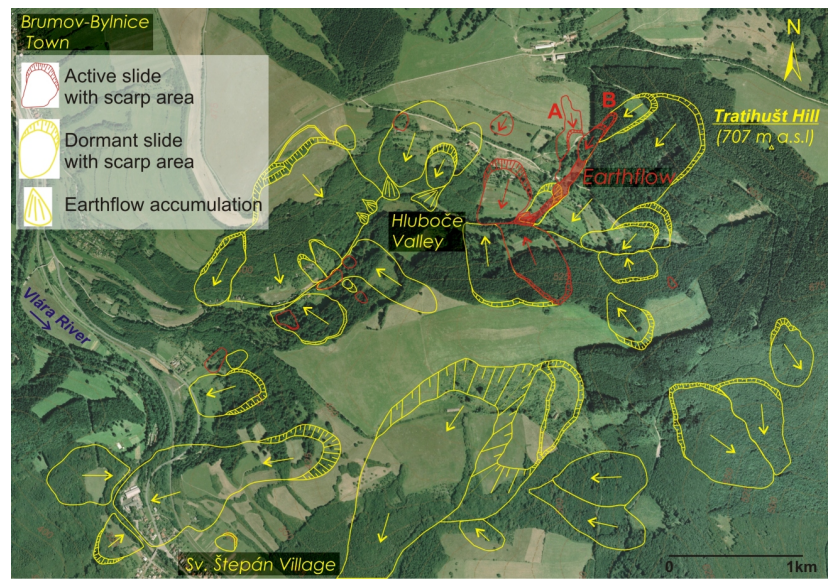

Fig. 3. Landslide inventory map of the Hluboče drainage basin, (A) and (B) refers to the parts of described landslide complex.

ter rock/soil and water sampling they were filled with soil. Moreover, four dynamic penetration tests DP-1, DP-2, DP-3 and DP-4 were situated along the landslide complex (Fig. 2). The BORROS machine (DIN 4094 standard) with cone diameter of $43.7 \mathrm{~mm}$, apex cross sectional area of $1500 \mathrm{~mm}^{2}$ and top angle of $90^{\circ}$ were used. The rammer weight was $50.0 \mathrm{~kg}$ and fall height $0.50 \mathrm{~m}$. Number of strokes per $100 \mathrm{~mm}$ penetration was recorded. Geotechnical strength tests of rock and soil samples were analysed in the laboratory of S.G. - GEOTECHNIKA Ostrava, whereas water samples were analysed in the laboratory of the UNIGEO Ostrava.

Sediment mineralogy of clay size particles was acquired for 4 colluvium samples (Fig. 2).

\section{Morphology and structure of the Hluboče landslide complex}

The active landslide complex is located within a large and much older deep-seated slope failure, which occupies almost entire southern slope of the Tratihušt' Mt. (Fig. 3). The activated part is $770 \mathrm{~m}$ long (ground surface length), maximally $110 \mathrm{~m}$ wide with relative relief of $186 \mathrm{~m}$. The total landslide area is about $60000 \mathrm{~m}^{2}$ and volume calculated according to Malamud et al. (2004) is estimated between $40000 \mathrm{~m}^{3}$ and $140000 \mathrm{~m}^{3}$. The maximum depth of shear plane estimated from the ERT profiles is $20 \mathrm{~m}$. The complex landslide is composed of different slope failure types. In the upper part, two active landslides "A" and " $B$ " developed. The western "A" landslide is rather shallow translational one (up to $10 \mathrm{~m}$ thick), whilst the eastern " $\mathrm{B}$ " is rotational and more than $10 \mathrm{~m}$ thick. Their toes joined in the middle of the slope. The rotational landslide transformed into an earthflow here (Fig. 2). The western translational "A" landslide is situated on the pasture and it starts with $1.2 \mathrm{~m}$ high headscarp (at an elevation of $592 \mathrm{~m}$ a.s.l.) where only soil and highly 

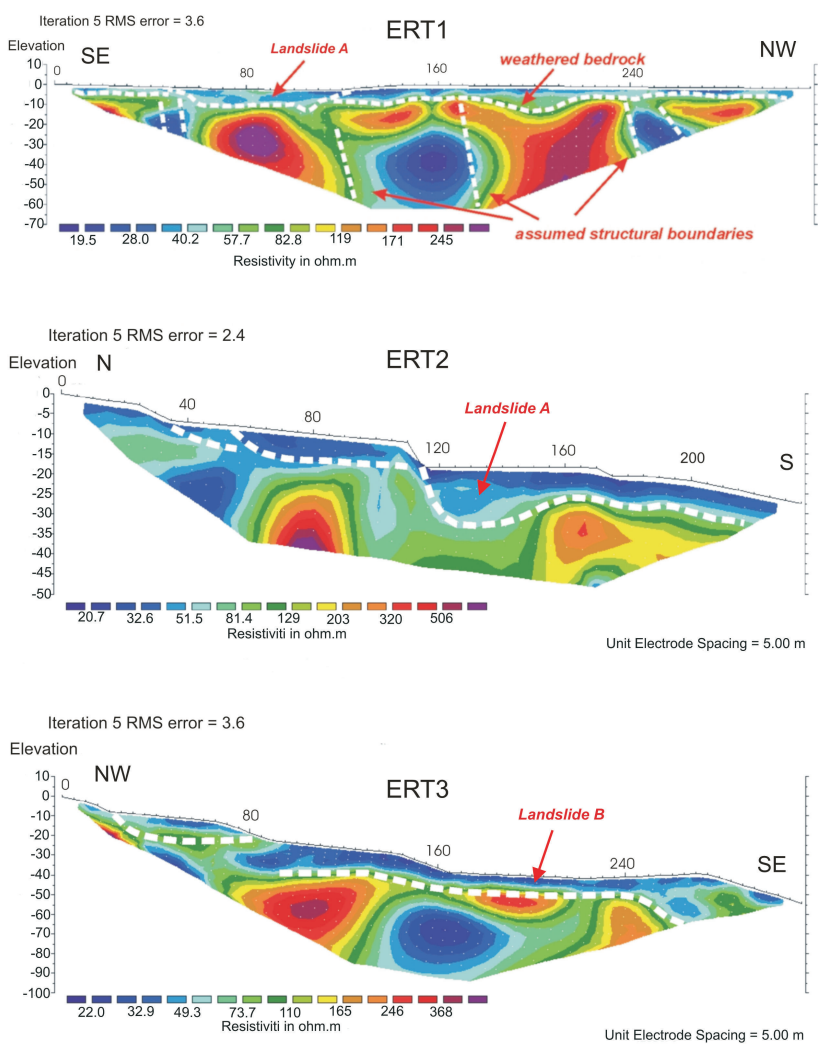

Fig. 4. Electrical resistivity tomography (ERT) profiles which location is depicted on Fig. 3.

weathered colluvium outcrop. Surface of the landslide body has irregular hummocky shape with very sharp, linear side limits. Several other headscarps, trenches and counter-slope scarps are located in the middle part of the slope, where culminate by $5 \mathrm{~m}$ high scarp at the elevation of $567 \mathrm{~m}$ a.s.l. (1 on Fig. 2) where also spring occurs. Bellow this scarp, the transport and accumulation part of the landslide "A" joints the accumulation of the landslide "B" (Fig. 2). A $27 \mathrm{~m}$ high scarp developed here subsequently.

The eastern landslide "B" (Fig. 2) reaches horizontal length of $255 \mathrm{~m}$, width of $50 \mathrm{~m}$. It has $9 \mathrm{~m}$ high recent scarp situated at elevation of $605 \mathrm{~m}$ a.s.l. where also only soil and highly weathered colluvium outcrop. However, an ancient head-scarp and several minor scarps were observed above the current landslide limit and morphologically well pronounced ancient accumulation was recognised near the forest limit (letter H4 on Fig. 2). These are evidences for previous activity of this part of the landslide complex.

Electrical resistivity tomography (ERT) profile through western "A" landslide depicts $6-13 \mathrm{~m}$ thick low-resistivity (20-60 $\Omega \mathrm{m}$ ) water-saturated landslide mass (Fig. 4). The resistivity survey verified about $10 \mathrm{~m}$ thick slightly back-tilted landslide block in the upper part of the eastern landslide "B" (Fig. 4).
Near the place, where slip-surfaces of the both landslides outcrop (below their junction), the slope failure starts to have a character of the earthflow accompanied by $3 \mathrm{~m}$ high lateral levee. Thickness of the earthflow varies from $2.5 \mathrm{~m}$ to $3.5 \mathrm{~m}$ and its maximum width is $68 \mathrm{~m}$. Toe moved through a shallow, dell-like slope concavity before it reached the valley bottom, where small brook was blocked. Dam was not formed due to the high water content and small thickness of the earthflow material.

Probable tectonic jointing was also observed in the ERT record (Fig. 4). Such tectonic jointing has weakened the bedrock strength properties, defined the principal unstable blocks and enabled different bedrock water-saturation and relatively deep weathering as visible in the ERT record. The ground-plan shape of the both recent landslides "A" and "B", diagonal to the principal slope and orthogonal to each other, as well as a shape of other old landslides in the surroundings also evoke strong tectonic control of the landslide complex evolution.

\section{Hydrogeology and physical properties of the landslide complex material}

The selected mechanical and strength properties of colluvial sediments and deeply weathered flysch bedrock forming the landslide complex body are in the Table 2. Majority of the values are similar, though the value of oedometric deformation module is 10 times higher for the bedrock than for the landslide material near the sliding surface. The bedrock is also less permeable which is largely due to clays formed during weathering of calystones which are predominant component of the Svodnice Formation. Sandstones are the strongest, least weathered element of the bedrock (measured strength in the simple compression is $137 \mathrm{MPa}$ ), but at the same time they are highly fractured enabling water percolation and accumulation. The landslide material near one of shear surfaces (dynamic penetration test site DP-3, Fig. 2) was characterized by residual values of angle of internal friction and cohesion and also lowest value of the oedometric deformation module showing the effects of shearing on the weathered colluvium.

Colluvial material covering the landslide complex is 2 to $5 \mathrm{~m}$ thick and is formed by poorly graded gravely clay or clayey gravel colluvium with stiff matrix. The gravel fraction is made by angular, weathered sandstone rocks in average $0.1 \mathrm{~m}$ in diameter. Its basic mechanical properties are in Table 2. The colluvium is characterized by low to medium plasticity $\left(I p=23 \%, w_{L}=48 \%\right)$ and very low activity of clay minerals $(A=0.45)$. This corresponds with results of the mineralogical analysis which showed that the content of smectite (major swelling and shrinking clay mineral) in four studied samples was negligible and reached maximally $8 \%$ (Table 3 ).

Dynamic penetration tests (DP-1, 2 and 3) showed important interface characterized by abrupt change of the values of 
Table 2. Mechanical properties of landslide complex material and rocks ( $\rho$ - unit weight, $\phi_{e f}-$ effective angle of internal friction, $c_{e f}-$ effective cohesion, $E_{\mathrm{def}}$,- oedometric deformation module, $\mu$ - Poisson number, $k_{f}$-infiltration coefficient)

\begin{tabular}{lllllll}
\hline Geotechnical type & $\rho\left(\mathrm{KN} . \mathrm{m}^{-3}\right)$ & $\phi_{e f}\left(^{\circ}\right)$ & $c_{e f}(\mathrm{kPa})$ & $E_{\mathrm{def}}(\mathrm{MPa})$ & $\mu$ & $k_{f}\left(\mathrm{~m} . \mathrm{s}^{-1}\right)$ \\
\hline $\begin{array}{l}\text { colluvial material within } \\
\text { the landslide body }\end{array}$ & 19.5 & 25 & 10 & 10 & 0.35 & $10^{-6}$ \\
$\begin{array}{l}\text { material near sliding surface } \\
\text { weathered flysh bedrock - }\end{array}$ & 19.5 & $20 * 0$ & $5^{*}$ & 4 & 0.35 & $10^{-6}$ \\
claystones with sand stones & & 25 & 15 & 40 & 0.30 & $10^{-7}$ \\
\hline
\end{tabular}

* residual values

the specific dynamic resistance in depth between 3.0 to $3.7 \mathrm{~m}$. Above this depth the specific dynamic resistance reaches values mostly around $5 \mathrm{MPa}$ or lower, whereas bellow the values always exceed $15 \mathrm{MPa}$. The DP-4 located close to the destroyed houses and more aside from the main landslide movement shows highly variable values of specific dynamic resistance with no clear interface.

Both colluvial sediments and weathered flysch bedrock have very low permeability - relatively more permeable colluvial sediments are overlying less permeable flysch rocks (mostly formed by claystones) with highly variable fissure permeability. This is typical hydrogeological setting within the flysch region, where the colluvial mantle is being partly saturating during high precipitation events (Michlíček, 1986). Important, long term concentration of underground water flow documents the spring located in the middle of the landslide complex (between sample locations $\mathrm{H} 2$ and $\mathrm{H} 3$, Fig. 2) with verified yield of 11 per minute (August 2006). The spring water is slightly basic $(\mathrm{pH}=7.7)$ with high mineral content (hard water).

\section{Eyewitness account}

According to the local residents and regional forestry workers, the main phase of the sliding took place between the 3 and 4 April 2006. The people woke up shortly after the midnight 2/3 April 2006 due to noise caused by the "B" landslide, which was destroying the forest. Subsequently, toe of the earthflow buried two houses in the lower part of the slope at 01:00-02:00 p.m. The flow accumulation reached the valley floor on the 4 April 2006, approximately between 04:00-05:00 p.m. The landslide surface velocity measured by forestry workers was $0.6-0.8 \mathrm{~m}$ per hour on the 4 April 2006. The major landslide activity stopped on the 4 April 2006, but minor displacement continued up to the 19 April 2006.

Some indications of the possible future activity of the landslide complex occurred several months before the catastrophic event. Local farmers observed that water completely disappeared from a spring, situated below the $5 \mathrm{~m}$ high scarp of the western " $A$ " landslide (Fig. 2) during the autumn 2005.
Table 3. Mineral content ( $\%$ of volume) of the clay fraction of the weathered bedrock $(\mathrm{H} 1)$ and colluvium material from headscarps (H2, H3) and landslide accumulation (H4). Ch - chlorite, I - illite, $\mathrm{K}$ - kaolinite, I-V - mixed structure illite-vermiculite, Sm smectite, Q - quartz, Plg - plagioclase, $\mathrm{Ca}$ - calcite

\begin{tabular}{ccccccccc}
\hline \multicolumn{10}{c}{ Minerals (\%) } \\
\hline Sample & Ch & I & K & I-V & Sm & Q & Plg & Ca \\
H1 & 2 & 21 & 1 & 4 & 8 & 45 & 4 & 15 \\
H2 & 7 & 27 & 12 & 3 & 7 & 32 & 5 & 7 \\
H3 & 13 & 22 & 10 & 6 & 6 & 35 & 3 & 5 \\
H4 & 11 & 22 & 8 & 6 & 4 & 34 & 4 & 15 \\
\hline
\end{tabular}

It could result from first movements on the future shear plane several months prior the main activity phase. On the other hand, several springs occurred in a shallow dell-like depression below the mapped landslides just before the landslide activity. Moreover, more than $2 \mathrm{~m}$ high artesian spring emerged at the central part of the earthflow directly above the destroyed house during the 3 and 4 April 2006 (Fig. 2). Also the antecedent activity of the landslide "A" was directly observed by local farmers, who noticed occasional evolution of tension cracks within the scarp area during past decades as well as during the autumn 2005. All these observations indicated slow changes in ground-surface morphology and hydrogeological regime which suggested the future landslide activity several months before the main landsliding phase (Burkhardt et al., 1972; Crosta et al., 2004).

\section{Landslide-complex kinematics}

Understanding its kinematics is one of the principal keys to better understand mechanism of the landslide-complex. As shown on the set of aerial photographs (Fig. 5), every part of the source area of the earthflow performed different values and vectors of the horizontal displacements. 


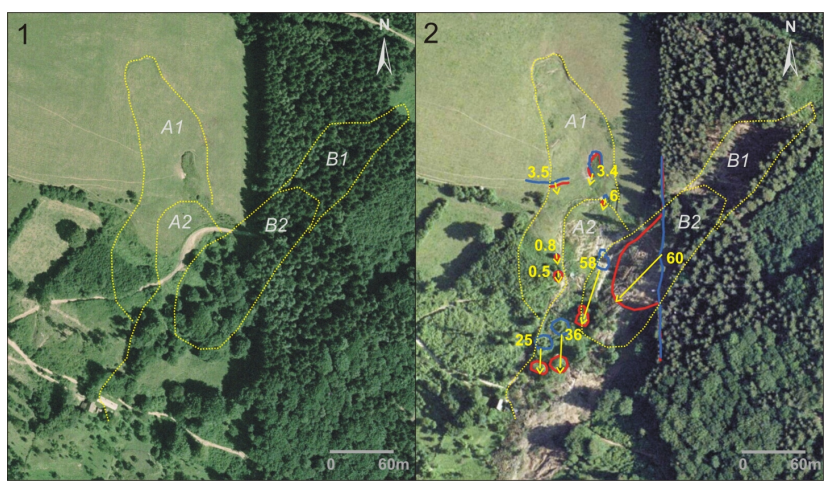

Fig. 5. Orthophoto from 2004 (1) shows contours of individual landslide bodies (dashed line) named A1, A2, B1 and B2; orthophoto from 2006 (2) shows original (blue) and displaced (red) positions of selected objects for which the displacement vectors (yellow arrows) and horizontal displacement in meters (yellow numbers) were identified.

The translational landslide "A1" had the lowest horizontal displacement between 0.5 to $3.5 \mathrm{~m}$. Mean displacement vector of this area was towards S. Rather rotational part "A2" moved in the same direction, but the displacement value reached up to $36 \mathrm{~m}$. The highest displacement occurred in lower (accumulation) part of the rotational landslide "B2", where the spruce-forest margin moved about $60 \mathrm{~m}$ towards SW. Such high values of the displacement resulted probably from subsequent liquefaction and flowing rather than from rotational sliding. The flow originated in this part of the landslide complex moved $350 \mathrm{~m}$ until it reached the valley bottom.

\section{Landslide-complex triggers}

The immediate triggering factor of the April 2006 Hluboe landslide complex was water saturation of its material due to mutual effect of snow melt water and high cumulative precipitations at the last days of March and beginning of April 2006 (Fig. 6, Bíl and Müller, 2008). Abnormally cold winter $2005 / 2006$ was characterised by very thick, long-lasting snow cover, which abruptly melted after sudden warming at the turn of March and April 2006 (Fig. 6). Maximal daily temperature varied between $14.4-18.6^{\circ} \mathrm{C}$ through 28 March and 2 April 2006. Additionally, total precipitation amount $(75 \mathrm{~mm})$ of March 2006 was $67 \%$ higher than the long-term average $(45 \mathrm{~mm})$. These climatic conditions produced exceptionally high values of total cumulative precipitation (143 $\mathrm{mm}$ at the nearest meteorological station) during the 2006 snow thaw period (Bíl and Müller, 2008) which was responsible for widespread occurrence of landslides. According to local residents, the sliding activity itself started 5 to $6 \mathrm{~h}$ after the main precipitation event.

\section{Previous landslide activity}

Age of the entire deep-seated slope failure was not radiometrically established so far. However, several ancient earthflow lobes (situated downstream from the studied landslide complex, Fig. 3) document activity of similar slope failures, which were also fed by material from deep-seated slope failures in the past. Previous major landslide activity in the site of Hluboče landslide complex is evidenced by soil buried by older landslide accumulation, nowadays exposed in one of the headscarps of landslide "B" (letter H4 on Fig. 2). Buried soil reveals AMS age $1435 \pm 30^{14} \mathrm{CBP}$ (calibrated age with probability $95.4 \%$ is 571 AD-656 AD) and gives maximum age of mass movement preceding recent landslide activity.

More detailed description of the landslide activity and land-use changes since 1950s is possible by analysing stereopairs of historical aerial photographs. Stereo-pairs from $\mathrm{Au}-$ gust 1950 clearly show the existence of a dormant slope failure in the place of the present landslide "A". An approximately $4 \mathrm{~m}$ deep and $30 \mathrm{~m}$ wide dell-like depression existed in the zone of the initial part of the earthflow. Photographs from September 1977 indicate activity within the landslide area "A". Moreover, an approximately $1 \mathrm{~m}$ high headscarp, a hummocky relief and bare surfaces are evident on the future landslide tension zone in the middle part of the slope. Sliding activity was not apparent in the landslide "B" due to dense forest. Based on the stereo-pairs from July 1990, both landslides ("A" and "B") seem to be inactive, but western landslide "A", situated on the meadow, can be morphologically recognized. Also the aerial photography from 2003 clearly depicts outline of the contemporary uppermost $1.2 \mathrm{~m}$ high headscarp of the western landslide ,A“" and small swampspring in the place of recent $5 \mathrm{~m}$ high scarp (Fig. 2).

The landslide "B" had already existed before the 2006 activation as evidenced by the headscarp and identified older accumulation near the forest limit. Moreover, the dendrochronologic analysis proved movement activity of the landslide "B" between years 1937 and 2006. Growth disturbances (eccentricity of annual rings caused by sudden tree tilting due to mass movements) were identified during this period (Fig. 7). The studied trees were tilted in different directions. Tilting upward the slope was typical for the trees growing on the main landslide block (B2 on Fig. 5). Trees growing in the compression part of the landslide " $\mathrm{B}$ " above the toe were tilted in all modes. This behaviour is typical for compression and rather plastic mass deformation (Baroň et al., 2004). The highest tree growth disturbances caused by landslide activity were detected at the end of 1950s (19571958), beginning and end of 1960s $(1961,1962,1967)$ and at the end of 1990s (1997).

Land use changes detected on the aerial pictures represent mostly reforestation without direct connection to the landslide complex. The reforestation started in the most cases between 1950 and 1970. Only the narrow forest stripe uphill of the study site was probably clear-cut and reforested during 

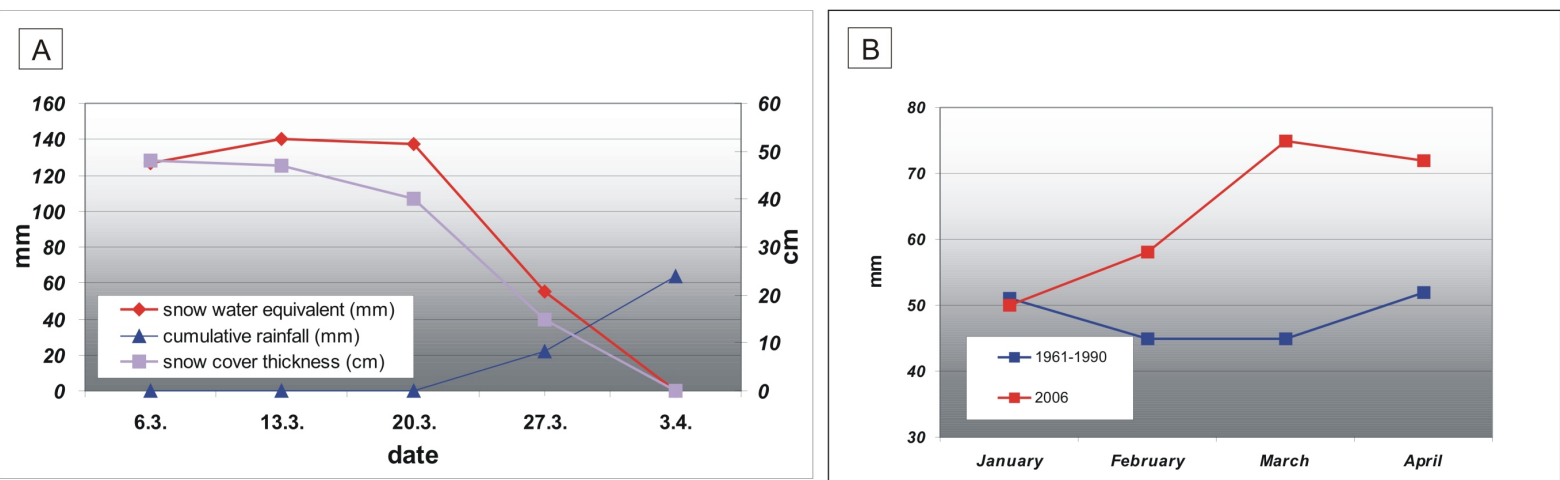

Fig. 6. Rapid thawing of the thick snow cover and increasing cumulative rainfall (A) along with above long-term average (1961-1990) monthly precipitations $(\mathbf{B})$ were main triggering factors of the landslide complex (data provided by Czech Hydrometeorological Institute and modified from Bíl and Müller, 2008).

the period 1977-1990. This is the only land-use change which may possibly affect the landslide complex hydrological conditions.

\section{Discussion}

The results of the Hluboče landslide complex investigations are useful for susceptibility analyses as well as landslide hazard prediction. Efficiency of their application largely depends on availability of the detailed and relevant landslide and geological information on regional scale. From this point of view, the presence of morphologically well pronounced older landslide bodies has the highest applicability for identification of potentially dangerous landslide locations. It is because the experiences from the flysch region have demonstrated that more than $40 \%$ of newly occurred landslides evolve within the older landslide bodies (Krejčí et al., 2002; Rybář, 1999) which also confirmed the Hluboče landslide complex. This finding was accented during landslide inventory mapping at the scale 1:10000, where also old, inactive landslides are shown. This mapping covers the majority of the Outer Western Carpathians on the territory of the Czech Republic (Krejčí et al., 2002). Its results show that in average $3 \%$ of the mapped flysch region in the Czech Republic is covered by landslides (Klimeš, 2007). Nevertheless, some areas can be covered with landslides from more than $10 \%$ and in the case of the Hluboče watershed, the coverage reaches up to $38 \%$ !

Information abut structural and tectonic conditions as well as about thickness of colluvial mantle could further improve the prediction of spatial landslide hazard, since these conditions proved to be important causative factors for landslide occurrence within the studied flysch rock environment. Unlikely the information about old landslide bodies, the detailed and reliable structural information is available only for some case study sites. More over landslide susceptibility models using information about structural conditions for regional as- sessment has not been successful due to paucity of bedrock outcrops and high local variability caused by detailed faulting (Klimeš, 2005) of the flysch region. Nevertheless, the structural information contained in the 1:50000 geological maps can be, with some caution, used as a proxy of local structural settings and if favorable conditions for landsliding (e.g. presence of faults, conform bedding plane dip with slope), coincide with presence of old landslide bodies, more attention should be paid to such areas.

The research also proved that long recognized indicators of future landslide activity (e.g. creep movement, opening cracks on the surface and abrupt hydrological changes) as well as evidences of major past activations (e.g. buried soil horizons within the landslide body) should be considered seriously for prediction of future landslide hazard in the flysch regions. Nevertheless, these indicators should be always judged carefully in a broader context of the selected study site considering that additional triggering factor (e.g. precipitations) of certain magnitude is needed to trigger the landslide.

The chronic nature of the Hluboča landslide complex activity with repeating phases of major activations during long time range was proved by buried soil horizon. The soil was buried by old deep-seated landslide preceding the recent landslide activity. Minimum age of the soil horizon indicating the major landslide activity acquired by $\mathrm{AMS}{ }^{14} \mathrm{C}$ dating is between $571 \mathrm{AD}-656 \mathrm{AD}$. It corresponds to the extremely humid phase of the Subatlantic chronozone with numerous dated landslides identified both in the Czech and Polish parts of the Western Carpathians (Margielewski, 2006; Pánek et al., 2009). The time range 500-800 AD, during which the landslide activity occurred, is also characterized by several palaeofloods documented in floodplains facies of rivers in the Polish part of flysch Carpathians (Starkel et al., 1996).

Detailed investigations of the physical properties of the landslide complex material revealed important and sufficiently detailed information about the studied site. The use 


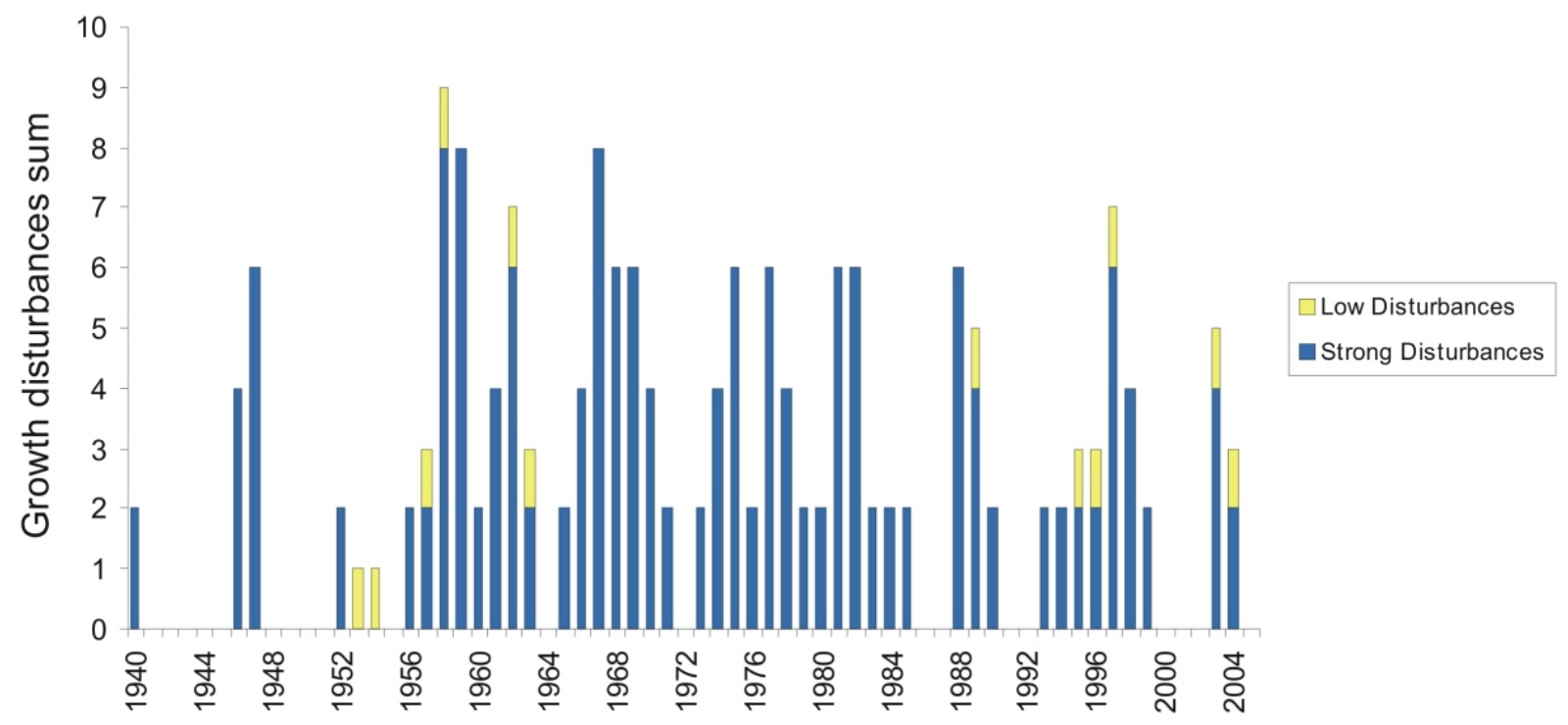

Fig. 7. Weighting sums of eccentric tree-rings per year. Low disturbances are defined by value of Ei=0.1-0.5, strong disturbances by Ei $>0.5$.

of this information for assessment of landslide susceptibility on similar setting or on regional scale is questionable for variety of reasons. The conducted research, as well as the most other similar studies, does not describe the same soil and rock properties outside the landslide area, thus the acquired physical properties can not be used to distinguish possibly unstable slopes from those with more stable conditions. Moreover our experience suggests that even if such data would be available, they may fail contribute to better identification of more susceptible sites due to highly overlapping physical properties or rocks outside and inside the landslide areas. The conducted dynamic penetration (DP) tests are probably detecting active shearing surface in the depth between 3.0 and $3.7 \mathrm{~m}$ with reworked landslide material above it. We think it is one of the more shallow shearing surfaces, which have not been detected by the ERT measurements due to coarser spatial resolution of the measurements than in case of penetration tests (vertical resolution of $0.1 \mathrm{~m}$ ). The DP-4 site describes the less disturbed material close to west landslide complex limit whereas the other DP test sites detect highly reworked landslide material in the centre of the landslide. These differences can be also contributed to different horizontal displacement rates (Fig. 5) and the fact, that the previous landslide activity probably did not extensively affect the DP-4 site where less disturbed colluvium and bedrock are preserved.

The low permeability of colluvium and flysch bedrock suggests the importance of preferential water flow paths for water infiltration (Šanda, 1998). These flow paths evolve due to heterogenity in colluvial material as well as highly variable, locally intense fracturing of the bedrock enabling water infiltration and its accumulation above less permeable layers of clay material. Occurrence of large number of landslides due to superficial water infiltration is well described also in areas with similar low values of infiltration coefficient (e.g. Cardinali et al., 1999; Klimeš, 2008). Initially we also thought that swelling/shrinking activity of particular clay minerals may enhance water infiltration effects on the landslide stability, but the analysed soil samples from the near surface zones contained only negligible portion of these minerals.

The liquefaction effect and development of rather shallow secondary landslides at the frontal parts of deep-seated rotational slope failures in the Flysch Belt of Outer West Carpathians similar to the Hluboče earthflow were noted by Barǒn et al. (2004). These shallow landslides are usually much more rapid and destructive than their deep-seated precursors as shows also the Hluboče landslide complex where the horizontal displacement vectors can be used as proxy of the movement velocities (Fig. 5). The factors causing development of such shallow secondary landslides and earthflows still remain a subject of discussion. Nevertheless, it seems that they mostly originate due to local bulkage, uplifting or tension of the material due to activity of the deepseated slope failures.

The dendrochronologic analyses of the studied site well correlate with reported landslide activations as well as records from comparable slope deformations. The ascertain activity of the landslide "B" in 1967 (Fig. 7) well correlate with landslide activation in adjacent area recorded by Špürek (1972). Similarly, 1957-1958, 1962 and 1997 activations very well correlate with results of dendrochronologic analysis of the Pustevny landslide (J. Burda, personal communication, 2008), which is situated about $50 \mathrm{~km} \mathrm{NNE}$ from the Hluboče landslide complex. Moreover, the year 1997 showing important eccentric tree-ring grow, was characterized by exceptional precipitations (July) causing large floods 
and triggering hundreds of landslides within the Outer Western Carpathians region (Krejčí et al., 2002).

Land use changes do not give reasonable explanation for landslide reactivation at the studied site. The historical aerial photo interpretation showed that reforestation was the main land use change detected throughout the last 50 years. On the other hand, some other field data from the broader area (Baroň et al., 2007) shows that majority of the mostly shallow landslides from the spring 2006 landslide event occurred on grassland or cropland suggesting that the land-use played important role in their spatial distribution. It may be due to faster melting outside the forest due to direct insolation, different snow cover thickness distribution within the forest and reinforcement effects of the tree roots. This observed spatial distribution of 2006 landslides contrasts with the distribution of landslides caused by heavy precipitation in July 1997 which occurred with equal probability within as well as outside forested areas (Klimeš, 2007).

Finally we tried asses the Hluboče landslide complex hazard, considering probability of occurrence of its triggering event, which was described by total cumulative precipitation (TCP) value of the sudden snow melt and precipitations. We used the probability of getting the equal or higher TCP value from the spring 2006 (143 $\mathrm{mm}$ at the nearest meteorological station) calculated by Bíl and Müller (2008) to $10^{-4}(0.12 \%)$. It is worth to note that $10 \%$ of the landslides from the spring 2006 occurred under or at $100 \mathrm{~mm}$ of TCP (Bíl and Müller, 2008), thus the given probability should be considered as more conservative one. Its reliability is affected by short period of meteorological records available for its calculation (20 years) and the fact that no effort has been done to include the influence of possible climatic changes on the future TCP values. We determined the landslide hazard as the product of its magnitude and TCP yearly occurrence probability. The landslide magnitude is a measure of the expected damage caused to people or infrastructure in front as well as on top of the landslide. Several landslide characteristics (e.g. velocity, area, volume, kinetic energy and potential energy) can be used to assess the landslide magnitude. Relating these values to the property damage, the magnitude for the Hluboče landslide complex is always 1 , since the total property damage occurred under observed landslide characteristics. It gives us the resulting hazard and specific risk to property loss equal to the TCP yearly occurrence probability which is $10^{-4}$. This value can be considered as low risk. Nevertheless it may not be acceptable from the point of view of local inhabitants since this low risk event was responsible for the total damage of their properties. On the other hand, the local authorities may perceive it as an acceptable risk level when comparing expenses of on site landslide mitigation measures and relocation of the residents to community houses.

\section{Conclusions}

The Hluboče landslide case study shows that even in the midmountain conditions of the Flysch Belt of the Outer Western Carpathians, large flow-like landslides can originate under specific geological and morphological settings with considerable destructive capability even though under slower movement rate. The April 2006 Hluboe landslide complex was triggered by the rapid snowmelt and intensive rainfall mobilizing gravitationally and tectonically disrupted and deeply weathered flysch bedrock and colluvium. The catastrophic activity occurred after several decades of slope movement rates ranging from creep to sliding and/or flowing. Evidences of the landslide activity were found on aerial pictures (only for areas outside the forest) and confirmed by interviewing of local inhabitants and interpreting dendrochronological analyses. The research suggests at least $\sim 1.5 \mathrm{ka}$ of landslide activity. The recent acceleration was not considerably affected by human intervention and resulted from internal dynamic of the studied landslide complex and extreme meteorological conditions.

Despite of evacuation of significant portion of the landslide mass in the form of the earthflow, considerable amount of unstable landslide material still remains thus increasing potential hazard for future development of the area.

This research shows how important are information about presence of antecedent landslide bodies and recognition of their ongoing movement activity for proper landslide hazard assessment. It also illustrates limitations of aerial photo interpretation which is not always capable to correctly detect these forms and indicators of their activity suggesting that field work is under presented natural conditions inevitable for accurate and reliable landslide information collection.

The application of lessons learned during the conducted investigation to improve spatial as well as temporal landslide hazard prediction limits small availability of sufficiently detailed and relevant data on regional scale. Therefore it can mainly help to improve landslide hazard assessment for single case studies where such data are more likely to be accessible.

Finally we tried asses the Hluboče landslide complex hazard considering probability of occurrence of its triggering event represented by the total cumulative precipitation (TCP) value of sudden snow melt and precipitations. We suggest that the probability of getting the equal or higher TCP value from the spring $2006(143 \mathrm{~mm}$ at the nearest meteorological station) should be used. This probability was calculated by Bíl and Müller (2008) to $10^{-4}(0.12 \%)$. We determined the landslide hazard as the product of its magnitude and yearly occurrence probability of its triggering mechanism. The magnitude of the Hluboe landslide complex is always 1, since it caused total property damage. It gives us the resulting hazard to property loss of $10^{-4}$ which can be considered as low. The landslide hazard calculated for the Hluboče landslide complex can be applied to other sites only if they hold 
similar properties including presence of previous landslide bodies still well morphologically pronounced and evidences of continuous creep movements.

Acknowledgements. The research was supported by these projects:

- Grant project of the Academy of Sciences of the Czech Republic, No. KJB301870501: “Quaternary geochronology of slope deformations of the culmination part of the Western Beskydy Mountains: absolute and relative dating of landforms";

- Project of the Czech Geological Survey 215124-2: "Slope Instabilities Management, their Geological Investigation and Monitoring", which is a part of the governmental program ISPROFIN (Ministry of the Environment of the Czech Republic) No. 215120 "Support of Prevention in the Areas Endangered by Unfavourable Climatic Events";

- Czech Science Foundation (GAČR) No. 205/05/2770, Endogenous factors of the slope failures - origin and evolution.

The authors would like also thank to A. Havlín, V. Baldík and O. Krejčí for their assistance during field research.

Edited by: T. Glade

Reviewed by: C. Prager and another anonymous referee

\section{References}

Baroň, I., Krejčí, O., and Prchal, J.: Fotoletecká dokumentace kalamitní aktivace mělkých svahových deformací na jaře 2006 na Zlínsku, in: Proceedings of International conference Slope deformations and pseuodo karst, 29-31 May 2007 in Vsetín, on CD, 2007.

Baroň, I., Cílek, V., Krejčí, O., Melichar, R., and Hubatka, F.: Structure and dynamics of deep-seated slope failures in the Magura Flysch Nappe, outer Western Carpathians (Czech Republic), Nat. Hazards Earth Syst. Sci., 4, 549-562, 2004,

http://www.nat-hazards-earth-syst-sci.net/4/549/2004/.

Bíl, M. and Müller, I.: The origin of shallow landslides in Moravia (Czech Republic) in the spring 2006, Geomorphology, 99, 246253, 2008.

Burkhardt, E., Liškutínová, D., and Plička, M.: Význačný sesuv u Oznice v Hostýnských vrších. Sborník Československé společnosti zeměpisné, 3, 219-225, 1972.

Cardinali, M., Ardizzone, F., Galli, M., Guzzetti, F., and Reichenbach, P.: Landslides triggered by rapid snow melting: the December 1996-January 1997 event in central Italy, in: Mediterranean Storms, Proceedings of the EGS Conference in Maratea, Italy, October 1999, 439-448, 1999.

Corsini, A., Pasuto, A., Soldati, M., and Zannoni, A.: Field monitorin of the Corvara landslide (Dolomites, Italy) and its relevance for hazard assessment, Geomorphology, 66, 149-165, 2005.
Crosta, G. B., Chen, H., and Lee, C. F.: Replay of the 1987 Val Pola Landslide, Italian Alps. Geomorphology, 60, 127-146, 2004.

Kirchner, K.: Klimatologie, in: Příroda Valašska (okres Vsetín), ČSOP ZO 76/06 Orchidea, Vsetín, Czech Republic, 61-66, 2001.

Klimeš, J.: Statistical and GIS based spatial analysis of factors contributing to the landslide evolution, Outer Western Carpathians, Czech Republic, in: Proceedings of the Conference, 15. Tagung für Ingenieurgeologie, Erlangen, Germany, 6-9 March 2005, 6166, 2005.

Klimeš, J.: Analysis of the preparatory factors of landslides, Vsetínské vrchy Highland, Czech Republic, Charles Univesity Prague, Czech Republic, Ph. D., 151, 2007.

Klimeš, J.: Deterministický model náchylnosti území ke vzniku svahových deformací ve Vsetínských vrších, Geografie - sborník ČGS, 113(1), 48-60, 2008.

Krejčí, O., Baroň, I., Bíl, M., Jurová, Z., Hubatka, F., and Kirchner, K.: Slope movements in the Flysch Carpathians of Eastern Czech Republic triggered by extreme rainfalls in 1997: A case study, Phys. Chem. Earth, 27, 1567-1576, 2002.

Krejčí, O.: Geologická mapa ČR 1:50000, list 25-43 Púchov, ČGÚ Praha, Czech Republic, map, 1992.

Malamud, B. D., Turcotte, D. L., Guzzetti, F., and Reichenbach, P.: Landslide inventories and their statistical properties, Earth Surf. Proc. Land, 29, 687-711, 2004.

Margielewski, W.: Records of the Late Glacial-Holocene palaeoenvironmental changes in landslide forms and deposits of the Beskid Makowski and Beskid Wyspowy Mts. Area (Polish Outer Carpathians), Folia Quaternaria, 76, 1-149, 2006.

Michlíček, E.: Hydrogeologické rajóny ČSR, svazek 2 Povodí Moravy a Odry, Geotest Brno, 165, 1986.

NASA: http://www2.jpl.nasa.gov/srtm/, last access: 22 December 2007.

Pánek, T., Hradecký, J., Minár, J., Hungr, O., and Dušek, R.: Late Holocene catastrophic slope collapse affected by deep-seated gravitational deformation in flysch: Ropice Mountain, Czech Republic, Geomorphology, 103, 414-429, 2009.

Pícha, F. J., Stráník, Z., and Krejèí, O.: Geology and Hydrocarbon Resources of the Outer West Carpathians and thei Foreland, Czech Republic, in: The Carpathians: Geology and Hydrocarbon Resources, edited by: Golonka, J. and Picha, F. J., AAPG Memoir, 49-176, 2004.

Rybář, J.: Rozbor příčin zvýšeného výskytu svahových deformací v České republice v červenci 1997, Geotechnika, 2, 7-14, 1999.

Starkel, L., Kalicki, T., Krapiec, M., Soja, R., Gebica, P., and Czyżowska, E.: Hydrological changes of valley floors in Upper Vistula Basin during the last 15000 years, Geographical Studies (Spec. Issue) IgiPZ PAN, Warsaw, 9, 7-128, 1996.

Šanda, M.: Proudění vody v pủdním profilu na svahu horského povodí. M.S. Doktorské disertaní minimum, ČVUT, Prague, Czech Republic, 56, 1998.

Špürek, M.: Historical catalogue of slide phenomena, Studia geographica 19, GGÚ ČSAV Brno, Czech Republic, 19, 180, 1972. 